\title{
Screening stress factors survey in an institute of advanced studies: health and safety integrated plans ${ }^{1}$
}

\author{
C.S. Fonseca ${ }^{\mathrm{a} *}$; C.N. Gomes ${ }^{\mathrm{a}}$ and F.S. Barros ${ }^{\mathrm{a}}$ \\ ${ }^{a}$ Brazilian Air Force Command, Aeronautical Institute of Psychology, Av. Marechal Câmara, 233, $8^{\circ}$ floor, RJ, \\ Brazil
}

\begin{abstract}
The current paper presents the study of organizational stressors survey carried out in a military institute, responsible for researches of high demand on aerospace technology. The study considered the theoretical framework of Organizational Ergonomics, combined with the technical guidelines of Psychology applied to Work Safety. The participatory approach was used on daily work assessment and decision making, aiming the adoption of corrective and preventive measures, considering possible distortions and imbalances between prescribed and actual activities. Thus, it was sought to engage and encourage the participation of the Institute's workers in the reflection/creation of better solutions to daily problems and to achieve productivity, without prejudice in the occupational health and safety.
\end{abstract}

Keywords: Stressors, organizational ergnomics, work safety

\section{Introduction}

The contemporary human work is suffering intense and rapid changes in operating methods, in its management and social relations established in the labor environment. High cognitive and psychosocial loads cause effort of adaptation of professionals who seek to answer to the market's competitive and globalized demands. Faced with the changes, new approaches on work are introduced, creating a temporary state of tension in place of the feeling of the balance achieved earlier.

Levels of stress may become more visible among members of an organization, causing health problems and psychological distress.

In contrast, organizations that deal with complex technological systems appear to be increasingly concerned to comply with safety requirements and to establish strategies to control risk.

In this sense, the current paper presents the project of organizational stressors survey developed in a military institute, responsible for researches of high demand in the area of aerospace technology. The specificity of this organization is that, despite being a military institution - with a rigid hierarchical structure and vertical and traditional values - its workers are, mainly, civilians (scientists).

\section{Theoretical bases}

The study considered the theoretical referential of the Organizational Ergonomics, combined with the technical guidelines of Psychology Applied to the Work Safety. It used the participatory approach to evaluate the daily work and decision making aiming the adoption of corrective and preventive measures, considering possible distortions and imbalances between actual and prescribed activities.

\section{Objectives}

The project was directed toward the following goals: to know the work particulars, to raise the inci-

\footnotetext{
$1 \quad$ E-mail: diset-ipa@ipa.aer.mil.br
} 
dence of organizational stressors, to identify signals that could indicate the presence of different levels of individual stress, to raise workers awareness about ways of managing everyday stress and to propose measures to manage organizational stressors, incorporating health and work safety activities at the Medical Control of Occupational Health Program, in force in the Organization.

\section{Methodology}

For the analysis of initial demand, the techniques used were unstructured interviews with leaderships, guided tours to work places and non-systematic observations. In the first stage of the study, a lecture was given for the workforce, presenting the theme Work \& Stress, aiming to sensitization and understanding of the phenomenon. On this occasion three instruments were used for data collection:

- Forced-choice questionnaire, constructed for the identification of organizational stressors. It focused on the areas of physical environment, equipment / instruments / tools, work organization, perks, safety, support material and interpersonal relationships.

- Scale of Relative Values of Work [10], for the assessment of value's importance degree (achievement in work, social relations, prestige and stability) as a guiding work principle.

- Stress Inventory [9], viewing the self-knowledge about the presence of levels and signs (physical, social, emotional, mental and spiritual) of individual stress.

The sample was composed randomly by 122 servers of various technical divisions and the administrative sector.

In the second phase of the study, GUT Matrix was applied to for prioritizing problems, according to the criteria of seriousness, urgency and trend of development of undesirable factors. Two discussion groups, composted by 22 (twenty two) workers were encouraged to consider the ramifications of the critical aspects pointed out from the matrix and to suggest appropriate actions for improvement.

\section{Discussion}

It was observed that the forms of dissatisfaction / demotivation / illness at work, as well as defensive strategies of the workers to face them are the result of the difficulties in negotiation between the individual interests / needs and organizational goals. Such difficulties in negotiation are expressed based on aspects that can be grouped into the following categories: working conditions, work organization and labor relations [1]. On the basis of this categorization, the discussion of the findings in the study was structured.

Working conditions refer to aspects such as physical environment, hygiene and safety conditions, and anthropometric characteristics of the workstation. During the discussion of the organizational problems of the Institute, such aspects, as previously stated, emerged as important factors that produce stress and threaten the relation between work and health. That's because employees understand that well preserved facilities, clean water and a comfortable and safe working environment, for example, take part in the scope of what is basic to the development of any work activity and constitute human needs which are not subject of any negotiation. When asked to give up these conditions, the worker feels that he is neglecting what is essential to maintaining their own health (physical and / or mental).

Organization of work means the division of labor, the task content, the hierarchical system, the command arrangements, the power relations and issues of responsibility. So, the way all facets of work organization are expressed can contribute positively or negatively to the regulation of the inevitable tension between individualism and cooperation [2], besides the maintenance or the damage on workers' psychic health. In this category, professionals identified as an imbalance factor the reduced the amount of professionals to fulfill the demand (load) of work. This condition has worsened since the number of employees, who retire each year, is significantly greater than the number of hires.

A problem caused by the evasion of professionals from the Institute concerns information management in the organization, since experienced employees have retired without the proper transmission of knowledge to the newcomers.

In relation to the command modalities, the researchers have been the group of more affected workers: as projects managers are periodically substituted; the continuity of works can be hindered.

The workers' speech also points out to a failure in the workflow within the organization, mainly characterized by the contradiction of objectives and rules [6]. The lack of an organized workflow can be the result of another problem cited by the workers: the inconsistent coordination between the sectors, which makes the creation of cooperation conditions diffi- 
cult. In this sense, it is noteworthy that the cooperation, as the possibility of integrating specific competencies of each worker, has the potential to minimize and circumvent individual errors and failures, causing the performance of collective power to result greater than the sum of individual performances [6].

The work relationships, in turn, include the questions that emerge in the relation to the hierarchy, to managers and other workers.

The workers in support sectors indicated a perception that their efforts are not recognized as workers employed in the survey are. Even the financial investment for the improvement of working conditions, it was reported that there are funds that are intended only to projects, which means that improvements are sectored.

Many workers reported that the problems could be summarized to just one: the chiefs' concern with the conditions of work of subordinates. They perceive that the problems are already known, but that there is not a mobilization from the part of superiors to solve them, thus hindering the relations with the hierarchy, especially the relations of trust.

There is also a perception that those who stand out positively end up being longer required because they are considered reliable. However, this supposed recognition generates overload and discontent in some workers.

\section{Proposals and Recommendations}

From the analyses presented in the previous topic, the main actions directed toward improvements suggested, which had been ratified by the operators, are: labor gymnastics; learning coping strategies and resilience; outsourcing of environmental conservation; review and restructuring of the work organization; optimization of physical conditions of work (with the support of ergonomics); redistribution of computer equipment; customized symbolic rewards to employees; creation of forums of discussion for presenting ideas about work and feedback from superiors on what is happening with the demands.

\section{Final considerations}

Finally, an effective management of stress must be aligned with the human resources policy of the Organization, having as main goals the improvement of life quality and the responsibility and commitment from all levels of leadership.

Therefore, we emphasize the importance of focusing on the efforts (subjective mobilization) daily performed by the workers, which involves a high human cost (and also financial) and may be covering up problems that might cause influence in future accidents or in the increase of illnesses rates. As a result, the focus on the mobilization of operators should not be limited to praise the effort made, but should allow the expansion of the conditions for the realization of a work which combines in the best way possible, quality, productivity, operations safety and workers health.

\section{References}

[1] C. Dejours. A loucura do Trabalho. São Paulo: Cortez, 11980.

[2] C. Dejours. O Fator Humano. São Paulo: Cortez, 11997.

[3] L. B. de S. Gianasi. As fontes de desgaste físico e emocional e a síndrome de Burnout no setor de transporte coletivo urbano de Natal. Natal: 2004. Dissertação (Mestrado) - Universidade Federal do Rio Grande do Norte. Centro de Ciências Humanas, Letras e Artes. Departamento de Psicologia. Programa de Pós-Graduação em Psicologia.

[4] F, Guérin, A. Laville, F. Daniellou, J. Durafoug, A. Kerguelen. Compreender o trabalho para transformá-lo: a prática daErgonomia. São Paulo: Blüncler: Fundação Vanzolini, 2001.

[5] A.C. Limongi-França, E.B. Arellano. Pessoas na organização. São Paulo: Ed. Gente, 2002.

[6] A.M. Mendes. Psicodinâmica do Trabalho: teoria, método e pesquisas. São Paulo: Casa do Psicólogo, 2007.

[7] A. Moraes, C. Mont'alvão. Ergonomia: Conceitos e Aplicações. Rio de Janeiro: IuSeR, 2003.

[8] J. Pérez-Ramos. Motivação no trabalho: abordagens teóricas. Psicologia USP, São Paulo, 1(2): 127-140, 1990.

[9] A. Rowshan. Stress an owner's Manual: Positive techniques for taking charge of your life. Oxford, England: Oneworld Publications, 1997.

[10] M. Siqueira et al. Medidas do Comportamento organizacional: Ferramentas de diagnóstico e de gestão. Porto Alegre: Artmed, 2008.

[11] P. Zarifian. Objetivo Competência: por uma nova lógica. São Paulo: Atlas, 2001 